\title{
Interconversion among 16-Membered Macrolide Antibiotics Belonging to Leucomycin-Maridomycin Group*
}

\author{
Masaru Suzuki, Tsutomu Takamaki, Ken-ichiro Miyagawa, Hideo Ono, \\ Eiji Higashide and Minoru UCHIDA
}

\author{
Microbiological Research Laboratories, Central Research Division, \\ Takeda Chemical Industries, Ltd., Japan
}

Received January 10, 1979

\begin{abstract}
To clarify the biosynthetic pathway of maridomycin, the biosynthetic relation among 16membered macrolide antibiotics belonging to leucomycin-maridomycin group was examined with intact cells or growing cultures of Streptomyces hygroscopicus No. B-5050-HA and its mutants.

Carbomycin A, B and leucomycin $\mathrm{A}_{3}$ were converted to maridomycin II in the $\mathrm{pH}$ range of $5.5 \sim 7.5$ with an optimum between $6.0 \sim 6.5$. But, maridomycin II was not converted to leucomycin $A_{3}$ or carbomycin $B$. These findings were confirmed by culture experiment. Leucomycin $\mathrm{A}_{3}$, carbomycin $\mathrm{A}$ and $\mathrm{B}$ added to the culture at $48 \mathrm{hr}$ were almost completely converted to maridomycin II.

On the basis of these facts, we propose a biosynthetic relation among leucomycin $A_{3}$, carbomycin A, carbomycin B and maridomycin II.
\end{abstract}

Recently, much attention has been paid to the biosynthesis and the interconversion of 16membered macrolide antibiotics such as carbomycin $\mathrm{A},{ }^{1 \sim 3)}$ platenomycin, ${ }^{4 \sim 77}$ leucomycin, ${ }^{8,9}$ tylosin, ${ }^{10,11)}$ maridomycin, ${ }^{12 \sim 17)}$ etc. The 16 membered macrolide antibiotics can be classified into two major groups depending on the difference in substituents at the 4-, 12-, 14-, and 15-positions of the lacton ring, as follows: (1) the leucomycin-maridomycin group containing carbomycin $\mathrm{A}$ and $\mathrm{B}$, platenomycin, SF-837, ${ }^{18}$ etc., and, (2) the tylosin-cirramycin ${ }^{193}$ group containing rosamicin, ${ }^{20}$ relomycin, ${ }^{11}$ etc.

The leucomycin-maridomycin group is further divided into four groups: (1) leucomycin group containing platenomycin, $\mathrm{SF}-837$, etc., (2) carbomycin A group containing deltamycin, ${ }^{25}$ (3) carbomycin B group containing $\mathrm{YL}-704 \mathrm{~W}_{1},{ }^{26)}$ etc., (4) maridomycin group containing $\mathrm{YL}-704 \mathrm{C}_{1}{ }^{26)}$ etc. These four groups differ from each other in the structures at C-9, and $\mathrm{C}-12, \mathrm{C}-13$ positions of the aglycone, as illustrated in Fig. 1.

In the course of a fermentation study on

\footnotetext{
* Studies on Maridomycin Fermentation. Part IV.
}

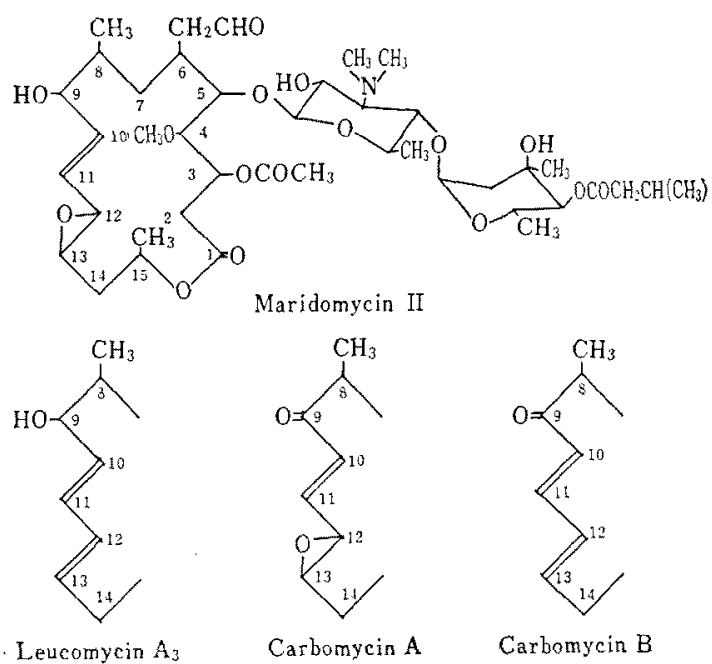

Fig. 1. Structures of Maridomycin II, Leucomycin $\mathrm{A}_{3}$, Carbomycin $\mathrm{A}$ and Carbomycin $\mathrm{B}$.

maridomycin, it was found that some mutants derived from a maridomycin producer, Streptomyces hygroscopicus No. B-5050-HA, produced a small amount of the other 16-membered macrolide antibiotics such as leucomycins, carbomycin A and B, as by-products along with maridomycin. In the fermentation by these mutants, the appearance of leuco- 
mycins, carbomycin A and B was observed mainly in the late phase of the fermentation. This observation suggested the two possibilities of microbiological interconversion among those antibiotics mentioned above, that is, (1) leucomycins, carbomycin A and B once produced were converted microbiologically to maridomycin in the early phase but not the late phase of the fermentation, or (2) maridomycin once produced was converted to leucomycins, carbomycin A and B in the late phase of the fermentation.

It would be great interest, therefore, to make clear the biosynthetic relation among 16membered macrolide antibiotics belonging to leucomycin-maridomycin group because of their structural similarity. A review on the structural relation of 16 -membered macrolide antibiotics has been published by Omura ${ }^{21)}$ et al., but microbiological interconversion of these macrolides has hardly been dealt with.

In this paper, we report the microbiological interconversion among 16-membered macrolide antibiotics belonging to leucomycinmaridomycin group.

\section{MATERIALS AND METHODS}

Microorganisms. Streptomyces hygroscopicus No. B-5050-HA, a maridomycin producer, and its mutants were used.

Media and cultivation. A spore suspension $(0.5 \mathrm{ml})$ of S. hygroscopicus No. B-5050-HA or its mutants was used to inoculate $200-\mathrm{ml}$ shake flask containing $20 \mathrm{ml}$ of seed medium consisting of $30 \mathrm{~g}$ of glucose, $30 \mathrm{~g}$ of corn steep liquer, $0.5 \mathrm{~g}$ of $\mathrm{MgSO}_{4} \cdot 7 \mathrm{H}_{2} \mathrm{O}$, and $3 \mathrm{~g}$ of $\mathrm{CaCO}_{3}$ per liter ( $\mathrm{PH}$ 6.5). The inoculum was incubated at $28^{\circ} \mathrm{C}$ for $48 \mathrm{hr}$ on a rotary shaker. One milliliter of the culture broth thus obtained was transferred into a $200-\mathrm{ml}$ shake flask containing $20 \mathrm{mI}$ of the medium consisting of $80 \mathrm{~g}$ of glucose, $30 \mathrm{~g}$ of corn steep liquer, $10 \mathrm{~g}$ of meat extract, $0.5 \mathrm{~g}$ of $\mathrm{NH}_{4} \mathrm{Cl}, 0.3 \mathrm{~g}$ of $\mathrm{MgSO}_{4} \cdot 7 \mathrm{H}_{2} \mathrm{O}$ and $10 \mathrm{~g}$ of $\mathrm{CaCO}_{3}$ per liter $(\mathrm{pH} 6.5$ ). Incubation was carried out on the rotary shaker at $28^{\circ} \mathrm{C}$ for $40 \mathrm{hr}$. Cells were harvested from the culture broth by centrifugation and washed once with sterile water, and then used as intact cells. In the fermentation experiment, $1 \mathrm{ml}$ of the seed culture described above was transferred into a $200-\mathrm{ml}$ shake flask containing $16 \mathrm{ml}$ of the medium consisting of $120 \mathrm{~g}$ of glucose, $20 \mathrm{~g}$ of Proflo, $5 \mathrm{~g}$ of soy been meal, $5 \mathrm{~g}$ of
$\mathrm{NH}_{4} \mathrm{Cl}, 1.2 \mathrm{~g}$ of $\mathrm{K}_{2} \mathrm{HPO}_{4}, 0.5 \mathrm{~g}$ of $\mathrm{MnSO}_{4} \cdot 4-6 \mathrm{H}_{2} \mathrm{O}$, $0.2 \mathrm{~g}$ of $\mathrm{MgSO}_{4} \cdot 7 \mathrm{H}_{2} \mathrm{O}, 1.0 \mathrm{~g}$ of $\mathrm{FeSO}_{4} \cdot 7 \mathrm{H}_{2} \mathrm{O}, 0.5 \mathrm{~g}$ of $\mathrm{ZnSO}_{4} \cdot 7 \mathrm{H}_{2} \mathrm{O}, 10 \mathrm{~g}$ of DL-methionine, $5 \mathrm{~g}$ of DL-alanine and $12 \mathrm{~g}$ of $\mathrm{CaCO}_{3}$ per liter ( $\left.\mathrm{pH} 6.5\right)$, and was incubated at $26^{\circ} \mathrm{C}$ for $144 \mathrm{hr}$ on the rotary shaker.

Analytical methods. Maridomycin was measured by the colorimetric method reported by Uchida et al. ${ }^{22}$ ) Leucomycin, carbomycin A and B were assayed by UV absorption at $231 \mathrm{~nm}\left(E_{1 \mathrm{~cm}}^{1 \% \%} 350\right), 238 \mathrm{~nm}\left(E_{1 \mathrm{em}}^{1 \% \%} 185\right)$ and $278 \mathrm{~nm}\left(E_{1 \mathrm{~cm}}^{1 \% 6} 276\right)$, respectively. Bioautography or high speed liquid chromatography was also employed, when it is necessary. Total potency of 16-membered macrolides was assayed by bioassay method using Bacillus subtilis PCI 219.

Chemicals. Maridomycin II was purified by partition or adsorption chromatography from the maridomycin complex. Leucomycin $\mathrm{A}_{3}$ was extracted from commercial preparation by the method of Suzuki et al. $^{23)}$ Carbomycin A and B were prepared from maridomycin II by the method of $\mathrm{Muroi}^{24)} \mathrm{et} \mathrm{al}$.

\section{RESULTS}

Interconversion of the 16-membered macrolide antibiotics belonging to the leucomycinmaridomycin group

To determine whether leucomycin $\mathrm{A}_{3}$, carbomycin $A$, carbomycin $B$ and maridomycin II were convertible to each other, the intact cells of Streptomyces hygroscopicus No. B-5050-HA and its mutant $\mathrm{M}-1382$, which lacked the enzyme for the reduction at $\mathrm{C}-9$ position of aglycone, were incubated with or without macrolides described above. As shown in Table I, carbomycin A was completely converted to maridomycin II with the intact cells of maridomycin producer (strain HA). Carbomycin $B$ was converted to leucomycin $A_{3}$ and maridomycin II. The maridomycin II formed from carbomycin $\mathrm{B}$ might be synthesized via leucomycin $\mathrm{A}_{3}$, because leucomycin $\mathrm{A}_{3}$ was easily converted to maridomycin II (carbomycin $\mathrm{B} \rightarrow$ leucomycin $\mathrm{A}_{3} \rightarrow$ maridomycin II). The other route, that is, carbomycin $B \rightarrow$ carbomycin $\mathrm{A} \rightarrow$ maridomycin $\mathrm{II}$ is also possible, because carbomycin B was converted to carbomycin A with the intact cells of strain M-1382. Leucomycin $A_{3}$ and maridomycin II were converted to carbomycin B and carbo- 
TABle I. Interconversion among Leucomycin $A_{3}$, Carbomycin A, CARBOMYCIN B AND MARIDOMYCIN II BY INTACT CellS

The reaction mixture contained $2.50 \mu$ moles of substrate and $100 \mathrm{mg}$ of washed cells (as dry weight) in a total volume of $5.0 \mathrm{ml}$ of $0.2 \mathrm{M}$ phosphate $(\mathrm{pH} 6.5$ ) or Tris-maleate buffer (pH 8.5), and was incubated at $30^{\circ} \mathrm{C}$ with shaking.

\begin{tabular}{|c|c|c|c|c|c|c|c|}
\hline \multirow{2}{*}{ Cells used $\left.{ }^{a}\right)$} & \multirow{2}{*}{ Substrate ${ }^{b}$} & \multicolumn{2}{|c|}{ Reaction condition } & \multicolumn{4}{|c|}{ Reaction products ( $\mu$ moles $/ \mathrm{ml}$ ) } \\
\hline & & $\mathrm{pH}$ & Time (hr) & $\mathrm{LM} \mathrm{A}_{3}$ & CM A & $\mathrm{CM} \mathrm{B}$ & MDM II \\
\hline \multirow{9}{*}{ No. B-5050-HA } & LM $\mathrm{A}_{3}$ & 6.5 & 4.0 & - & $\mathrm{ND}$ & $\mathrm{ND}$ & 0.37 \\
\hline & $\mathrm{LM} \mathrm{A}_{3}$ & 8.5 & 4.0 & - & ND & 0.10 & 0.01 \\
\hline & $\mathrm{CM} \mathrm{A}$ & 6.5 & 1.0 & $\mathrm{ND}$ & - & ND & 0.50 \\
\hline & $\mathrm{CM} \mathrm{B}$ & 6.5 & 1.0 & 0.19 & ND & - & 0.30 \\
\hline & MDM II & 6.5 & 4.0 & $\mathrm{ND}$ & ND & ND & - \\
\hline & MDM II & 8.5 & 4.0 & ND & 0.11 & ND & - \\
\hline & None & 6.5 & 1.0 & $\mathrm{ND}$ & ND & ND & 0.01 \\
\hline & None & 6.5 & 4.0 & ND & ND & ND & 0.02 \\
\hline & None & 8.5 & 4.0 & ND & ND & ND & 0.01 \\
\hline \multirow{3}{*}{ No. $\frac{B-5050}{\mathrm{M}-1382}$} & $\widehat{C M A}$ & 6.5 & 18.0 & ND & - & ND & ND \\
\hline & CM B & 6.5 & 18.0 & ND & 0.38 & - & $\mathrm{ND}$ \\
\hline & None & 6.5 & 18.0 & $\mathrm{ND}$ & 0.01 & $\mathrm{ND}$ & ND \\
\hline
\end{tabular}

a) The cells were harvested after cultivation for $40 \mathrm{hr}$.

b) Each substrate was dissolved in the aqueous solution with succinic acid.

ND: Not detectable.

Abbreviations: $\operatorname{LM~} A_{3}$, leucomycin $A_{3} ; C M A$, carbomycin $A ; C M ~ B$, carbomycin B; MDM II, maridomycin II.

mycin $\mathrm{A}$, respectively. The optimum $\mathrm{pH}$ of the reduction at $\mathrm{C}-9(\mathrm{O}=\mathrm{C}<\rightarrow \mathrm{OH}-\mathrm{C}\langle\mathrm{H})$ was $6.0 \sim 6.5$, and that of the reverse reaction $\left(\mathrm{HO}-\mathrm{C}^{\prime} \mathrm{H} \rightarrow \mathrm{O}=\mathrm{C}<\right.$ ) was $8.0 \sim 8.5$. The conversion of leucomycin $A_{3}$ to maridomycin II, and carbomycin $B$ to carbomycin $A$ was observed with the intact cells of strain $\mathrm{HA}$ and those of strain $\mathrm{M}-1382$, respectively. The optimum $\mathrm{pH}$ of the epoxidation at $\mathrm{C}-12$ and $13\left(-\mathrm{HC}=\mathrm{CH} \rightarrow-\mathrm{HC}^{\prime} \mathrm{O} C \mathrm{CH}-\right)$ was $6.0 \sim 6.5$.

From the data obtained above, the interconversion among these 16 -membered macrolides with the intact cells is summarized as follows;

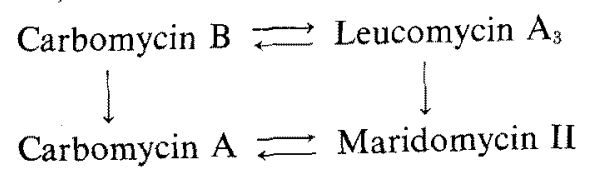

Relation between conversion activities and the accumulation of leucomycin-maridomycin group macrolides

In the course of strain development, we have succeeded in the isolation of a predominantly leucomycin-accumulating mutant (A23-6), a carbomycin $\mathrm{A}$ and $\mathrm{B}$-accumulating mutant (M-1382), and a both leucomycin and maridomycin-accumulating mutant (B-11M). The conversion activities of these mutants are summerized in Table II. As seen in Table II, the carbomycin $\mathrm{A}$ and B-accumulating mutant, $M-1382$, was found to lack the reductase of the $\mathrm{C}-9$ position. Leucomycin-accumulating mutant, A23-6, had strong reductase activity of $\mathrm{C}-9$, but the epoxidation activity of $\mathrm{C}-12$ and 13 was hardly observed. Both leucomycin and maridomycin producer, $\mathrm{B}-11 \mathrm{M}$, had strong activity of the reduction of C -9 and moderate activity of the epoxidation of $\mathrm{C}-12$ and 13.

From these data, it may be concluded that maridomycin II is synthesized via two pathways in the fermentation, that is, (i) carbomycin $B \rightarrow$ leucomycin $\mathrm{A}_{3} \rightarrow$ maridomycin II, or (ii) carbomycin $\mathrm{B} \rightarrow$ carbomycin $\mathrm{A} \rightarrow$ maridomycin II. 
Table II. Comparison of Conversion Activity by the Washed Celis of Several Mutants

\begin{tabular}{|c|c|c|c|c|c|c|}
\hline \multicolumn{7}{|c|}{ Ratio of bioconverted product $(\%)$} \\
\hline Cells used & $\underset{\mathrm{CM} B}{\mathrm{CM} A}$ & $\underset{\mathrm{CM} \mathrm{B}}{\mathrm{C}}$ & $\underset{\mathrm{LM} \mathrm{A}}{\mathrm{CA}}$ & $\begin{array}{l}\mathrm{CM} \mathrm{A} \\
\mathrm{MDM}\end{array}$ & 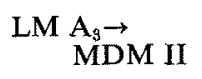 & $\operatorname{MDM} \underset{\mathbf{L M}}{\operatorname{II}} \mathrm{A}_{3}$ \\
\hline A23-6 & ND & ND & 100 & 100 & ND & ND \\
\hline M-1382 & 75 & ND & ND & ND & ND & ND \\
\hline $\mathrm{B}-11 \mathrm{M}$ & ND & ND & 80 & 100 & 10 & ND \\
\hline No. BH & & & & & & \\
\hline 5050-HA & ND & ND & $50^{a}$ & 100 & 50 & ND \\
\hline
\end{tabular}

The experimental methods are the same as described in the footnote of Table $\mathrm{I}$. The reaction $\mathrm{pH}$ is 6.5 .

a One half of $\mathrm{LM} \mathrm{A}_{3}$ formed is considered to be converted to MDM II, because no CM B remains.

Table III. Comparison of Conversion Activity by 48 hr Cultured-cells AND 120 hr Cultured-CElls

\begin{tabular}{|c|c|c|c|c|c|c|c|}
\hline \multirow{2}{*}{$\begin{array}{l}\text { Cells } \\
\text { used }\end{array}$} & \multirow{2}{*}{$\begin{array}{l}\text { Cultured } \\
\text { time (hr) }\end{array}$} & \multirow[b]{2}{*}{$\mathrm{CM} \underset{\mathrm{CM} A}{\mathrm{~B} \rightarrow}$} & \multicolumn{5}{|c|}{ Ratio of bioconverted product $(\%)$} \\
\hline & & & $\underset{\mathrm{CM} \mathrm{B}}{\mathrm{C}}$ & $\underset{\mathrm{LM} \mathrm{A}_{3}}{\mathrm{C}}$ & $\begin{array}{l}\mathrm{CM} A \rightarrow \\
\mathrm{MDM}\end{array}$ & $\underset{\mathrm{MDM}}{\mathrm{LM} \mathrm{A}_{3}}$ & $\underset{\mathbf{L M ~ A}}{\operatorname{MDM} \mathrm{II} \rightarrow}$ \\
\hline No. BH 5050 & 48 & ND & ND & $50^{a}$ & 100 & 50 & ND \\
\hline$-\mathrm{HA}$ & 120 & ND & ND & 90 & 98 & 5 & ND \\
\hline \multirow[t]{2}{*}{ M-1382 } & 48 & 75 & ND & ND & ND & ND & ND \\
\hline & 120 & 5 & ND & ND & ND & ND & ND \\
\hline
\end{tabular}

The experimental methods and ${ }^{a}$ mark are the same as described in the footnote of Table II.

Changes of conversion activities during the fermentation

Effect of cell age on the conversion activities was examined with $48-\mathrm{hr}$ cultured cells and $120-\mathrm{hr}$ cultured cells. Table III shows the results obtained. The epoxidation activities of leucomycin $\mathrm{A}_{3} \rightarrow$ maridomycin II or carbomycin $\mathrm{B} \rightarrow$ carbomycin $\mathrm{A}$ were observed with $48 \mathrm{hr}$-cultured cells, but hardly observed with $120 \mathrm{hr}$-cultured cells. The intact cells of M1382 had not the epoxidation activity of leucomycin $\mathrm{A}_{3} \rightarrow$ maridomycin II. So, it may be considered that the epoxidase for leucomycin $\mathrm{A}_{3} \rightarrow$ maridomycin II is not the same that for carbomycin $\mathrm{B} \rightarrow$ carbomycin $\mathrm{A}$. The reduction activity of $\mathrm{C}-9$ was constant during the course of fermentation.

To confirm the conversion of these 16membered macrolides, fermentation experiments were carried out. Table IV shows the results. The addition of leucomycin $A_{3}$, carbomycin A or B to the culture at $48 \mathrm{hr}$ enhanced the production of maridomycin II. The macrolides added to the culture were almost completely converted to maridomycin
Table IV. Conversion of 16 Membered MACrolmes in the Fermentation by S. hygroscopicus No. B-5050-HA

\begin{tabular}{lrcc}
\hline $\begin{array}{c}\text { Macrolide } \\
\text { added }\end{array}$ & $\begin{array}{c}\text { Addition } \\
\text { time }(\mathrm{hr})\end{array}$ & $\begin{array}{c}\text { Marido- } \\
\text { mycin } \\
\text { produced } \\
(\mu \mathrm{g} / \mathrm{ml})\end{array}$ & $\begin{array}{c}\text { Conversion } \\
\text { ratio }(\%)\end{array}$ \\
\hline LM A $_{3}$ & 48 & 6750 & 97.5 \\
& 120 & 4900 & 5.0 \\
CM B & 48 & 6680 & 94.0 \\
& 120 & 4820 & 1.0 \\
CM A & 48 & 6800 & 100.0 \\
& 120 & 6720 & 96.0 \\
MDM II & 48 & 6820 & - \\
& 120 & 6800 & - \\
None & - & 4800 & - \\
\hline
\end{tabular}

Each macrolide was added to the fermentation medium at the concentration of $2000 \mu \mathrm{g} / \mathrm{ml}$.

II. The conversion of maridomycin II to other macrolides was hardly observed when it was added to the culture. However, when the additions were made at $120 \mathrm{hr}$, only carbomycin A was converted to maridomycin II. The addition of carbomycin $B$ to the culture of strain M-1382 at $48 \mathrm{hr}$ enhanced the production of carbomycin A. The conversion of 
carbomycin A to carbomycin B, when the former was added to the culture at $48 \mathrm{hr}$, was not observed. Carbomycin B added to the culture at $120 \mathrm{hr}$ was not converted to carbomycin A.

These findings agree with the facts observed with the intact cells.

\section{DISCUSSION}

Omura et al., have investigated the origin of the skeletal carbons in the lactone ring of the 16-membered macrolide antibiotics, and clarified that the aglycone of leucomycin is derived from 5 acetate, 1 propionate, 1 butyrate and 1 unknown precursor corresponding to two carbons. Furumai et $a l_{.}{ }^{477}$, have proposed the biosynthetic pathway of platenomycins, a family of the 16-membered macrolide antibiotics belonging to leucomycin-maridomycin group, and presented the three biosynthetic routes from platenolide to platenomycin. However, up to now, nobody attempted to clarify the biosynthetic interrelation among the 16-membered macrolide antibiotics belonging to leucomycin-maridomycin group. So, we attempted to make clear the relation among these four macrolides, that is, leucomycin $\mathrm{A}_{3}$, carbomycin A, carbomycin B and maridomycin II. The experimental results described in this paper lead to conclusion that maridomycin II is biosynthesized as follows;

$\rightarrow$ Carbomycin $\mathrm{B}_{\searrow \text { Ceucomycin } \mathrm{A}_{3}}^{\nearrow \text { Carbomycin II }}$

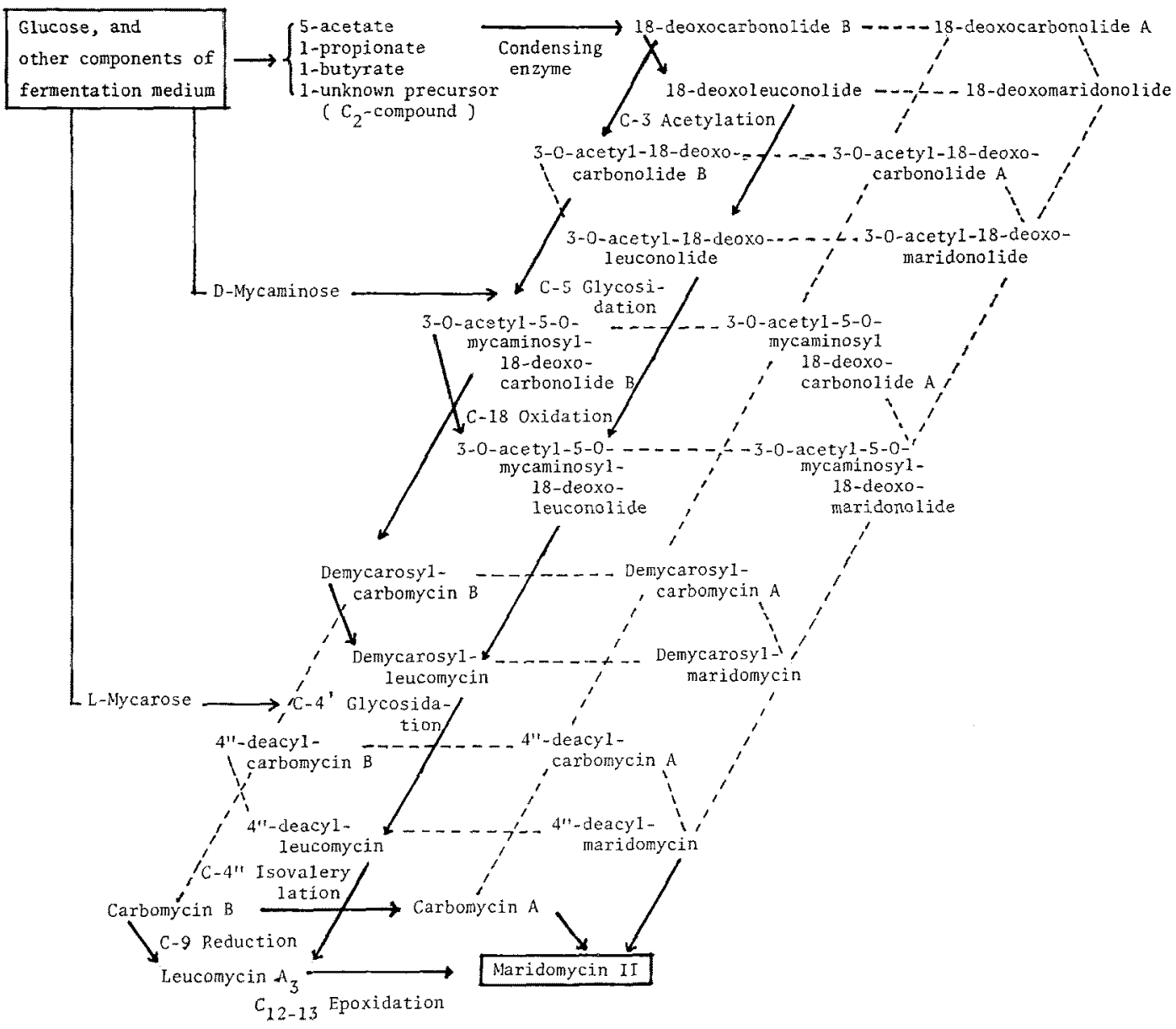

The stages indicated by broken lines are hypothetical

FIg. 2. Tentative Scheme to Illustrate the Possible Course of Maridomycin II Biosynthesis. 
On the basis of the experimental results of this paper and the reports of Furumai et al., and Omura et al., the biosynthetic pathway of the 16-membered macrolide antibiotics belonging to leucomycin-maridomycin group can be drawn as shown in Fig. 2. As is evident from Fig. 2, maridomycin is considered to be the end product of the macrolides described above. Until now, many strains such as $S$. halstedii, $S$. kitasatoensis, $S$. platenoensis, $S$. hydroscopicus, etc., have been reported as the 16membered macrolide antibiotics producers. $S$. halstedii (carbomycin A and B producer) is considered to be a blocked mutant of $\mathrm{C}-9$ reductase of the aglycon. $S$. kitasatoensis (leucomycin producer) is considered to be a blocked mutant of $\mathrm{C}-12$ and -13 epoxidase. $S$. hygroscopicus No. B-5050-HA (maridomycin producer) is considered to be a strain having strong $\mathrm{C}-9$ reductase and $\mathrm{C}-12,-13$ epoxidase. Therefore, S. hygroscopicus No. B-5050-HA produces a large amount of maridomycin.

Acknowledgment. The authors are very grateful to Drs. R. Takeda, K. Mizuno, T. Kishi and M. Asai of Takeda Chemical Industries, Ltd., for their interest and encourangement during the study, and also to $\mathrm{Mr}$. K. Fukuda for his skillful assistance.

\section{REFERENCES}

1) H. Grisebach and H. Achenbach, Z. Naturforsch., 176, 6 (1962).

2) D. Srinivasan and P. R. Srinivasan, Biochemistry, 6, 3111 (1967).

3) H. Grisebach and C. A. Weber-Schilling, $Z$. Naturforsch, 23b, 655 (1968).

4) T. Furumai and M. Suzuki, J. Antibiotics, 28, $770(1975)$.

5) T. Furumai and M. Suzuki, ibid., 28, 775 (1975).

6) T. Furumai and M. Suzuki, ibid., 28, 783 (1975).
7) T. Furumai, K. Takeda and M. Suzuki, ibid., 28, 789 (1975).

8) S. Omura, H. Takeshima, A. Nakagawa, J. Miyazawa, F. Piriou and G. Lukacs, Biochemistry, 16, 2860 (1977).

9) S. Omura and H. Takeshima, J. Biochem., 75, 193 (1974).

10) S. Omura, A. Nakagawa, H. Takeshima, J. Miyazawa, C. Kitao, F. Piriou and G. Lukacs, Tetrahedron Lett., 4503 (1975).

11) L. I. Feldman, I. K. Dill, C. E. Holmlund, H. A. Whaley, E. L. Patterson and N. Bohonos, Antimicro. Agent. Chemoth., p. 54 (1963).

12) K. Nakahama, M. Izawa, M. Muroi, T. Kishi, M. Uchida and S. Igarashi, J. Antibiotics, 27, 425 (1974).

13) K. Nakahama, T. Kishi and S. Igarashi, ibid, 27, 487 (1974).

14) K. Nakahama, T. Kishi and S. Igarashi, ibid., 27, 433 (1974).

15) K. Nakahama and S. Igarashi, ibid., 27, 605 (1974).

16) H. Ono, S. Harada and T. Kishi, ibid., 27, 442 (1974).

17) M. Suzuki, T. Takamaki, K. Miyagawa, H. Ono, E. Higashide and M. Uchida, Agric. Biol. Chem., 41, 419 (1977).

18) T. Tsuruoka, S. Inoue, T. Shomura, N. Ezaki and T. Niida, J. Antibiotics, 24, 526 (1971).

19) H. Koshiyama, M. Okanishi, T. Ohmori, T. Miyaki, H. Tsukiura, M. Matsuzaki, and $\mathbf{H}$. Kawaguchi, J. Antiboitics, 16, 59 (1963).

20) G. H. Wagman, J. A. Waitz, J. Marquez, A. Muracushi, E. M. Oden, R. T. Testa, and M. J. Weinstein, J. Antiboitics, 25, 641 (1972).

21) S. Omura and A. Nakagawa, ibid., 28, 401 (1975).

22) M. Uchida, M. Suzuki, T. Takayama and N. Sugita, Agric. Biol. Chem., 43, 847 (1979).

23) T. Suzuki, M. Asai and N. Sugita, Japan Patent, applied Tokukaisho 48-76880, laid open (1973).

24) M. Muroi, M. Izawa, H. Ono, E. Higashide and T. Kishi, Experientia, 28, 878 (1972).

25) K. Ohama, A. Koki, Y. Mutoh, Y. Shimauchi and T. Ishikura, J. Ferment. Technol., 55, 347 (1977).

26) M. Suzuki, I. Takamori, A. Kinumaki, Y. Sugawara and T. Okuda, J. Antibiotics, 24, 904 (1971). 